\title{
The Child's Right to Protection against Economic Exploitation in the Digital World
}

\author{
Simone van der Hof, ${ }^{a}$ E. Lievens, ${ }^{b}$ I. Milkaite, ${ }^{c}$ V. Verdoodt, ${ }^{d}$ \\ T. Hannema, ${ }^{e}$ T. Liefaard $f$ \\ a) Professor; Center for Law and Digital Technologies (eLaw), Leiden \\ University, Leiden, The Netherlands, Leiden \\ s.van.der.hof@law.leidenuniv.nl \\ b) Professor; Faculty of Law and Criminology, Research group Law \& \\ Technology, Ghent University, Ghent, Belgium \\ E.Lievens@UGent.be \\ c) Faculty of Law and Criminology, Research group Law \& Technology, \\ Ghent University, Ghent, Belgium \\ Ingrida.Milkaite@UGent.be \\ d) Dr; London School of Economics, Department of Law, London, UK \\ V.Verdoodt@lse.ac.uk \\ e) LL.M; Kennedy Van der Laan, Privacy department, Amsterdam, \\ The Netherlands \\ Thijs.Hannema@kvdl.com

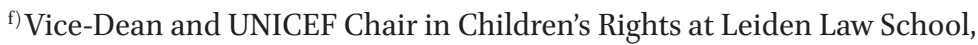 \\ Leiden University, Leiden, the Netherlands \\ t.liefaard@law.leidenuniv.nl
}

\begin{abstract}
Children face significant consumer risks when surfing online, related to, inter alia, embedded advertisements and privacy-invasive practices, as well as the exploitation of their incredulity and inexperience resulting in overspending or online fraudulent transactions. Behind the fun and playful activities available for children online lie complex revenue models, creating value for companies by feeding children's data into algorithms and self-learning models to profile them and offer personalised advertising or by nudging children to buy or try to win in-app items to advance in the games they play. In this article we argue that specific measures against these forms of economic
\end{abstract}


exploitation of children in the digital world are urgently needed. We focus on three types of exploitative practices that may have a significant impact on the well-being and rights of children - profiling and automated decision-making, commercialisation of play, and digital child labour. For each type, we explain what the practice entails, situate the practice within the existing legislative and children's rights framework and identify concerns in relation to those rights.

\section{Keywords}

privacy - data protection - economic exploitation - children - UNCRC

The child's right to protection against economic exploitation is enshrined in Article 32 of the United Nations Convention on the Rights of the Child (UNCRC). Although Article 32 UNCRC is generally interpreted as the child's right to protection against child labour (the right to be protected 'from economic exploitation and from performing any work that is likely to be hazardous or to interfere with the child's education') (Swepston, 2012: 15, authors' emphasis) in this contribution we argue that, in the digital environment, children need protection against a myriad of economically exploitative practices. In its general comment on the implementation of the rights of the child during adolescence, the UN Committee on the Rights of the Child confirmed that ' $\mathrm{r}$ ] eaching adolescence can mean exposure to a range of risks, reinforced or exacerbated by the digital environment, including ... economic exploitation ...' (United Nations Committee on the Rights of the Child, 2016).

Economic exploitation is not defined in the UNCRC but should be understood as being broader than child labour in the traditional sense (Swepston, 2012). First, "economic" implies that there is a material interest, i.e. 'a certain gain or profit through the production, distribution or consumption of goods and services' (United Nations Committee on the Rights of the Child, 1993: 3). This material interest may have an impact on the economy of either the State, the community or the family, such as the increased consumption of advertised goods or services which in turn leads to an increased gain or profit for the brand or company (Verdoodt, 2020). Second, "exploitation" means 'taking unjust advantage of another for one's own advantage or benefit' (United Nations Committee on 
the Rights of the Child, 1993: 3). More specifically, this includes manipulation, misuse, abuse, victimisation, oppression or ill-treatment and entails disrespect for the 'human dignity of the child or the harmonious development of the child's personality' (United Nations Committee on the Rights of the Child, 1993:3).

The digital world in which children grow up offers great opportunities for children to learn, socialise and play, but it is also increasingly commercialised. The Organisation for Economic Co-operation and Development (OECD) has underlined that children face significant consumer risks when surfing online, related to, inter alia, embedded advertisements and privacy-invasive practices, as well as the exploitation of their incredulity and inexperience resulting in economic risks such as overspending or online fraudulent transactions (OECD, 2012). Behind the fun and playful activities available for children online lie complex revenue models, creating value for companies (the material interest) by feeding children's data into algorithms and self-learning models to profile them and offer personalised advertising or by nudging children to buy or try to win in-app items to advance in the games they play (manipulation). ${ }^{1}$ The commercial aspects of the playful and social activities that children engage in when they access the digital environment are largely and often deliberately concealed from them (and often also from their parents). The so-called "dark patterns" are practices used to unconsciously manipulate individuals with intentionally deceptive user interfaces that have become increasingly more sophisticated in the digital environment. ${ }^{2}$ Moreover, often unknowingly to them or their parents, children's behaviour is continuously tracked by companies offering them digital services or third parties (such as AdTech companies). ${ }^{3}$ The practices, although different, have a common aspect, in that children and their identities have become

1 The line between persuasion and manipulation (as a form of exploitation) may in practice not always be entirely clear but the latter entails persuasion with the intention of tricking or controlling individuals for the purpose of encouraging them towards actions not otherwise taken, such as buying or believing something. Manipulation can include various strategies such as concealing or presenting information in ways that are misleading, undermining the capacity for practical reasoning and reflection, or targeting a person's vulnerabilities (see Barnhill, 2016).

2 An example of a dark pattern is directing gamers to in-app purchases while clicking a button that looks like you are merely starting a new game. Tricking individuals into sharing more personal data than they would have wilfully done if they had been made aware of the practices is also an example of a dark pattern. See e.g.: https://www.darkpatterns.org.

3 Advertising technology companies are companies that provide (re)targeted advertising services to other companies based on behavioural data. 
commodities. The same can be said for new forms of work in the digital world in which children also are more and more engaged, such as vlogging, ${ }^{4}$ social media influencing ${ }^{5}$ and e-Sports. ${ }^{6}$

Such forms of commercialisation of children's surroundings can have a negative impact on various children's rights, which may be even more significant when commercial practices result in the manipulation or abuse of children. Children's rights ${ }^{7}$ that are potentially impacted (Lievens et al., 2018) are the rights to non-discrimination (Article 2 UNCRC), the child's best interests (Article 3 UNCRC and Article 24 of the Charter of Fundamental Rights of the EU (CFREU)), development (Article 6 UNCRC), privacy (Article 16 UNCRC and Article 8 of the European Convention on Human Rights (ECHR), Article 7 CFREU), data protection (Article $8 \mathrm{CFREU}$ ), freedom of expression (Article 13 UNCRC, Article 10 ECHR Article 11 CFREU) and of thought (Article 14 UNCRC, Article 9 ECHR, Article 10 CFREU), health (Article 24 UNCRC), education (Articles 28 and 29 UNCRC), rest, leisure and play (Article 31 UNCRC) and protection against economic exploitation (Article 32 UNCRC). ${ }^{8}$ These and other rights are interlinked and may be impacted simultaneously by certain practices, although the exact impact is still unknown.

Children today are growing up in an era where 'data can be used to learn, deduce or infer much more about individuals than ever before' (Children's

4 Vlogging means video blogging which has become a popular activity on video-sharing platforms, such as YouTube, and allows for monetary gain when a sufficiently big subscriber base is attracted; see e.g.: https://www.wikihow.com/Earn-Money-on-YouTube.

5 Influencers are people with a substantial audience on social media platforms, such as Instagram, who use their personality to build strong personal and social connections with their followers in order to impact purchase decisions. Vloggers can be influencers.

6 Electronic sports or e-Sports are video gaming competitions increasingly also including professionalised sponsored teams. See, for example, the e-Divisions, in which e-Sportsmen (contracted by professional football clubs) compete against each other in the FIFA football game for a whole season or during tournaments, among them also minors. As an example we refer to the Dutch Edivisie https://www.edivisie.nl/ and the English ePremierleague https:// www.premierleague.com/epl.

7 Article 24 of the Charter of Fundamental Rights of the European Union (CFREU) states that: 1. Children shall have the right to such protection and care as is necessary for their wellbeing. They may express their views freely. Such views shall be taken into consideration on matters which concern them in accordance with their age and maturity.

2. In all actions relating to children, whether taken by public authorities or private institutions, the child's best interests must be a primary consideration. ...

8 This article does not focus on online sexual exploitation of children although it can also entail forms of economic exploitation of children. 
Commissioner for England, 2018: 4). Widespread data aggregation and practices entail the combination of "seemingly innocuous" information which can in fact become very telling and informative when combined (Children's Commissioner for England, 2018). In more detail, while '[a]ny individual piece of information may not be particularly intimate or personal, ... its sum total can paint a detailed picture' about a person (Waldman, 2018: 65) which can then be used for commercial profiling and automated decision making. And of course, whereas this is true for all individuals - children and adults alike - it is a fact that nowadays children are exposed to these practices from the moment of birth (or even before) and are "datafied" exponentially throughout their lives (Lupton and Williamson, 2017) while they go through different stages of physical, mental and psychological development. Most importantly, the longterm effects thereof on children's experiences, opportunities and life prospects are not yet known (Children's Commissioner for England, 2018).

In order to adapt to this new reality - considering that children are early adopters of new technologies accessing commercialised digital environments for play, communication, education and information from a very young age (Chaudron, 2015; Stoilova et al., 2019) - we argue that specific measures against these forms of economic exploitation of children in the digital world are urgently needed. In this article, we focus on three types of exploitative practices that may have a significant impact on the well-being and rights of children - profiling and automated decision-making, commercialisation of play and digital child labour. For each type, we explain what the practice entails, situate the practice within the existing legislative and children's rights framework and identify concerns in relation to those rights. We conclude with a number of recommendations for States, business actors and scholars.

2

\section{Profiling and Automated Decision-making and the Economic Exploitation of Children}

One of the momentous challenges in the digital environment is to protect children from profiling and automated decision-making that might adversely affect them. Children's online behaviour is continuously recorded, often sold, analysed and acted upon (Van der Hof, 2018). Advergames (i.e. games promoting a brand or product to the player), for example, collect personal information from the playing child in order to make the game visually more attractive to him or her, thus making them more susceptible to the underlying product (Verdoodt et al., 2016). Connected toys can record, analyse and remember children's conversations, and may integrate targeted references to products 
in those conversations (Milkaite and Lievens, 2019). In addition to automated decisions for marketing purposes, profiling and automated decision-making are also used to make (other) far-reaching decisions, such as placing child data subjects on a blacklist, offering or withholding certain rights or options, establishing learning trajectories (based on what is called learning analytics) and other applications. Although automated decision-making can be used for the well-being of children (e.g. for health-related purposes), it also carries the significant risk of infringing individual rights and freedoms, including those of children. The process and the nature of automated decision-making can be intrusive in itself, and the (possible) consequences of an automated decision can also be profound. Risks range from security issues, such as data leaks and identity theft, the occurrence of errors, such as false positives or false negatives, bias and discrimination, ${ }^{9}$ and black box decisions. ${ }^{10}$

One of the concerns expressed by the Council of Europe regarding profiling and automated decision-making is that profiling, without the implementation of specific legal safeguards, may negatively affect human dignity and infringe on fundamental rights and freedoms. ${ }^{11}$ Human dignity, i.e. respecting the intrinsic worth and uniqueness of every human being, can be at stake because automated decision systems have a de-individualising effect in two ways: the decision is taken on the basis of a digital identity, and it may be that it is not the person themselves who is central, but the group to which the person belongs to on the basis of their characteristic(s) (Vetzo et al, 2018). This also directly relates to the right to privacy (personal autonomy), the right to develop and express one's identity as an individual human being, and the right to non-discrimination when automated decisions and profiling unjustly affect certain groups in society (Vetzo et al., 2018).

Similarly, automated decisions can lead to discrimination of children and unequal treatment (e.g. by what is called digital redlining ${ }^{12}$ or by putting a

9 Automated decision-making and profiling can be prone to bias because they replicate and reinforce structural societal bias, such as racism and sexism, by basing decisions or profiles on a common trait of a group, such as ethnicity, gender or nationality, which may result in discriminatory practices. At the same time, if implemented with great care, such systems may perhaps be able to prevent discrimination that comes with human bias and prejudice; see Vetzo et al., 2018: 49, 139.

The inner workings of automated decision-making and profiling systems are often opaque, making it hard to explain, understand and challenge the outcome.

11 It is also important, however, to point out that fundamental rights law enshrines important values and principles that provide safeguards against the negative implications of automated decision-making and profiling. See Council of Europe, 2010.

12 Digital redlining entails the use of digital technologies for the purpose of singling out groups in society, such as ethnic minorities, in order to, e.g., systematically deny them particular services or target them with higher prices. See Capps, 2019, on the health impact for children as a result of redlining; see Martin, 2016, on educational redlining. 
baby on a no-fly list ${ }^{13}$ ) (Article 2 UNCRC). Automated decisions can exclude (groups of) children, by not giving them similar opportunities in more or less the same circumstances. Think of adaptive learning programmes by which the opportunities of some children are potentially increased or reduced compared to other children, because of certain input data that is used to profile children or because of the selling of data related to such programmes to third parties. In addition, automated decisions can violate the right to privacy of children, as defined in Article 16 UNCRC. The right to privacy encompasses the right to data protection (United Nations Committee on the Rights of the Child, 2016), and requires that the collection and processing of personal data - for instance to profile a child - should comply with legal requirements. In addition, the right to privacy inherently protects the shaping, development and representation of one's identity, and is as such linked to Article 6 UnCRC. Pursuant to Article 6 UNCRC, a child has the right to develop in harmony on a mental, physical, spiritual and social level. It may be the case that the continuous monitoring and commercialisation of children's data and identities has a negative impact on their development. Attributing children with a pre-defined profile could result in only experiencing opportunities, suggestions, information and choices tailored to that profile. The child is, in so doing, deprived of the opportunity to receive information (e.g. news, or advertising) which an algorithm would consider uninteresting or irrelevant to them, thus, hindering the child's development and opportunity to experiment throughout their childhood. It has been found that companies which target children and process their personal information influence children's opinions and development because they are profiled in a certain way on the basis of their gender, previous interests or (inter) actions online (Norwegian Consumer Council, 2016).

Profiling may entail inferring private and intimate information about children, such as sexual preferences, political, cultural or social background, race or health, without children themselves sharing such information (or even being aware of the profiles being created and used) (Norwegian Consumer Council, 2018; Van der Hof, 2019). From a commercial perspective these constructed digital persona can be valuable commodities, but by inferring (sensitive) data, a child's right to be in control of developing their digital identity might be violated as they have no or very little say in terms of opaque automated decisions made about them without their knowledge.

Moreover, it could be argued that profiling and automated decision-making for commercial purposes can constitute an infringement of Article 32 (1)

13 Ten weeks-old baby Naseer Muhammad Ali was put on the no-fly list of an airline on the basis of profiling and was then refused at the border (CBC News, 2016). 
UNCRC on the right to protection against economic exploitation. Profiles of children are economically very valuable, because knowledge about their behaviour and interests enables companies to send targeted advertising and offer personalised products and services (Verdoodt and Lievens, 2017b), and to build a consumer relationship from a very young age. In the digital environment, this can be witnessed through the introduction of services such as YouTube Kids and Facebook Messenger Kids, Amazon Echo Dot Kids, Google accounts for children. Moreover, data are sometimes exploited multiple times and by multiple parties. A website can sell behavioural data of a child to the highest bidder during real time bidding (exploitation moment 1 ), after which this bidder can use the knowledge to send an advertisement to this child in the hope that they buy a certain product (exploitation moment 2). Such practices are common in today's digital market but nevertheless remain very opaque. For example, the privacy and data policies of Instagram, Snapchat and TikTok, all state that their users' personal information may be shared with business partners and third parties which, however, are very rarely named and listed (Milkaite and Lievens, 2020). Moreover, profiling practices can be seen as manipulative because there is an element of unfairness and deception by coding the digital environment in such a way that children, without being sufficiently aware or understanding of it, are enticed to reveal far more data than would be justified in accordance with their expectations or preferences. Children are seduced by apps to keep clicking, swiping, liking and spending more and more time online (Van der Hof, 2015; Information Commissioner's Office, 2019).

Moreover, the commercialisation of children's digital identities through profiling happens in ways that are often completely non-transparent to children and parents (Van der Hof, 2015). Not only the fact that profiles are created and used, but also how they are created, who creates them, to whom they are sold and what consequences they have, remains opaque. This opaqueness occurs, notwithstanding existing obligations with regard to the provision of information concerning the collection and processing of personal data in a concise, transparent, intelligible and easily accessible form, using clear and plain language (Article 12 of the EU General Data Protection Regulation (GDPR)). ${ }^{14}$ Children (and their parents) can end up in a Kafkaesque "computer says no" situation in which "the computer" takes over the decision-making process without, for example, giving the data subject a further explanation or the ability to

14 The General Data Protection Regulation is the EU's most important legislative instrument regarding data protection principles, responsibilities of data controllers and rights of data subjects. For more information on this Regulation, in particular in relation to children, see Lievens and Verdoodt, 2017; Van der Hof et al., 2020. 
challenge an outcome. This is very problematic given that such decisions and predictions based on profiling can simply be incorrect (false positives or false negatives), since probabilities rather than objective truths are calculated on the basis of algorithms. All this impacts various children's rights, such as their right to access reliable and transparent information (Article 12 GDPR), in particular if this information is relevant to protect their best interests (Article 3 UNCRC) and their development and well-being (Article 6 UNCRC), as well as their right to be heard (Article 12 UNCRC), for instance, when challenging an outcome.

Article 3 of the UNCRC requires the best interests of the child to be a primary consideration in all actions, hence including those of private actors (United Nations Committee on the Rights of the Child, 2013a). Therefore, considerable weight must be placed on the best interests of children when making automated decisions about children, taking into account the adequacy and fairness of using such systems in and of themselves, their - potentially harmful - consequences for children and their wellbeing, as well as the increasing imbalance of power between children (and their parents) and tech or marketing companies. Note, however, that Article 3 states that the best interests of the child should be $a$, not the, primary consideration and thus will, in practice, be weighed against the interests of powerful companies that may very well be the direct opposite to those of children. Yet, the UN Committee on the Rights of the Child has emphasised in its General Comment, that 'the child's interests have high priority' and that '[ $t$ ] herefore, a larger weight must be attached to what serves the child best' (United Nations Committee on the Rights of the Child, 2013a).

Finally, in this context, there is an important tension between participation and protection, which States should keep in mind when developing guidance documents and policies in relation to profiling and automated decision-making in respect of children. On the one hand, States should develop guidelines for increased transparency and raise awareness of profiling activities and behavioural advertising, both amongst children and parents. On the other hand, States should consider default limits to the processing of children's personal data for the creation and use of profiles and the making of automated decisions for commercial purposes to protect children's rights and wellbeing. The question whether such default limits should depend on the evolving capacities of the child (Article 5 UNCRC) is challenging (Verdoodt and Lievens, 2017a). According to Varadan, the "evolving capacities of the child" are seen by the UN Committee on the Rights of the Child, not only as an interpretative and policy principle, but also as an enabling principle, entailing that 'as children grow, develop and mature, they acquire capacities to exercise increasing levels of agency over their rights' (Varadan, 2019). While in theory service 
personalisation based on different child age and maturity levels could be introduced, in practice this might not be obvious for a variety of reasons. Even though companies including Facebook, Google and Amazon have introduced specific services aimed at their child audience, it has been shown that they are either not widely used by children as they are less appealing and limited (for example, children prefer using YouTube over YouTube Kids) (Stoilova et al., 2019), or that these child services might not reach a high child protection standard (Harris, 2016; Wendling, 2017; Hern, 2019a, 2019b; Kang, 2019; Kelion, 2019; Lee, 2019; Timberg, 2019a, 2019b). It has also become apparent that companies tend to avoid service personalisation based on user age, let alone different child ages and developmental levels, as it is more expensive and burdensome (Gibbs, 2018). Stricter data protection standards for children thus sometimes result in children being excluded from different services. Both global and smaller companies now set the age limit for setting up accounts at 13-, 14-, 15- or 16-years old in the context of the United States Children's Online Privacy Protection Act or the EU GDPR (Montgomery and Chester, 2015). Yet, because of the major impact of profiling and targeting, the overall commercialisation of childhood, and the opaqueness of such data processing techniques, leading to difficulties to exercise agency, it could be argued that it is in the bests interests of all children, meaning all under 18-year olds, to be offered additional protection, by imposing restrictions on data controllers regarding the creation and use of profiles and the making of automated decisions for commercial(ly exploitative) purposes. Support for this is found in the UN Committee on the Rights of the Child's General comment No. 20 where it states that:

In seeking to provide an appropriate balance between respect for the evolving capacities of adolescents and appropriate levels of protection, consideration should be given to a range of factors affecting decision-making, including the level of risk involved, the potential for exploitation, understanding of adolescent development, recognition that competence and understanding do not necessarily develop equally across all fields at the same pace and recognition of individual experience and capacity (United Nations Committee on the Rights of the Child, 2016: 6, authors' emphasis).

Given the potential impact of automated decision-making and profiling on children' rights, the Council of Europe advises to prohibit profiling unless allowed by law and in the best interests of the child (Council of Europe, 2018). The matter is also addressed in EU data protection law, more specifically in Article 22 of the GDPR (European Parliament and Council, 2016). However, 
the prohibition only applies to the solely ${ }^{15}$ automated decisions that produce a legal or similarly significant effect. Moreover, despite the fact that attention is paid to the special position of children (recital 71, GDPR), it remains unclear which types of decisions will be considered to have a legal or similarly significant effect on them (Van der Hof and Hannema, 2018). Up until now, the only guidance that exists in this respect is the recommendation by the Article 29 Working Party (and its successor, the European Data Protection Board) ${ }^{16}$ to refrain from profiling children for marketing purposes, as:

solely automated decision making which influences a child's choices and behaviour could potentially have a legal or similarly significant effect on them ... Children can be particularly susceptible in the online environment and more easily influenced by behavioural advertising. For example, in online gaming, profiling can be used to target players that the algorithm considers are more likely to spend money on the game as well as providing more personalised adverts. The age and maturity of the child may affect their ability to understand the motivation behind this type of marketing or the consequences (Article 29 Working Party, 2018a: 29).

In its age appropriate design code, the United Kingdom (UK) Information Commissioner's Office (ICO) suggests switching off options which use profiling by default 'unless [the service] can demonstrate a compelling reason for profiling, taking account of the best interests of the child' (Information Commissioner's Office, 2020: 7,64 ). The ICO also proposes that profiling should only be allowed if the service has 'appropriate measures in place to protect the child from any harmful effects (in particular, being fed content that is detrimental to their health or well-being)' (Information Commissioner's Office, 2020: 64).

Aside from EU data protection law, EU consumer protection law could also provide for a safety net for children in the context of automated decision-making

15 There could still be some human involvement in the decision-making, e.g., when 'there is some evidence that even where systems are explicitly intended only to support a human decision maker, for reasons of trust in automated logic, lack of time, convenience or whatever, then the system tends to de facto operate as wholly automated', see Veale and Edwards, 2018.

16 The European Data Protection Board (EDPB) is established by Article 68 GDPR and is composed of the head of one supervisory authority of each Member State and of the European Data Protection Supervisor. 
and profiling for commercial purposes (Verdoodt, 2020). More specifically, the Unfair Commercial Practices Directive (UCP Directive) protects consumers including children - from unfair business-to-consumer commercial practices, including aggressive commercial practices. A commercial practice is considered aggressive if it 'by harassment, coercion or undue influence significantly impairs the freedom of choice or conduct of the average consumer' (Article 8 UCP Directive; European Parliament and Council, 2005). Although actual harassment or coercion (including the use of physical force) are not relevant in this particular context, the milder form of influence - undue influence - could be applicable (Article 2 (j) UCP Directive). The qualification of undue influence will depend on the specificities of a particular case, and the average consumer will be the benchmark (European Commission, 2016). Therefore, when it comes to vulnerable consumers (Chiarella, 2009), such as children, who are particularly susceptible to commercial pressure, the assessment should take into account children's innocence resulting in a much lower threshold than for adults. However, the actual assessment of determining what a typical reaction of a child would be in relation to a specific commercial practice is left up to the national courts and authorities, while taking into account the case law of the CJEU. In such an assessment the first element that needs to be present is the exploitation of 'a position of power in relation to the consumer so as to apply pressure' (Article 2 (j) UCP Directive). In the context of behavioural advertising, it has been argued that advertisers hold a position of power as they collect a lot of personal information of consumers (including children) without them being aware of what is happening (BEUC, 2010). The repetitive aspect of targeted advertising (e.g. through retargeting on social media) may qualify as applying pressure on consumers. Second, the pressure must be applied 'in a way which significantly limits the consumer's ability to make an informed decision' (Article 2 (j) UCP Directive). In this regard, it can be argued that the selection of advertisements based on the presumed consumer choice may prevent the display of other advertisements, thereby restricting the comparison with other advertisements and, hence, making an informed commercial decision (BEUC, 2010).

Children and their families are also exposed to a commercialisation of play. They are being targeted by game and toy manufacturers, who embed commercial messages directly into children's gaming experiences both online and offline. Examples of such marketing strategies include the delivery of 
commercial messages through in-game advertising, advergames, or even interactive, connected toys. Moreover, games may rely on in-app purchases for continuous play or to achieve higher levels. Especially what are called "freemium games" (the game is for free but premium features must be purchased) are notorious in nudging users into buying virtual items or functionality. In addition, gambling elements are increasingly integrated into children's games, such as slot machines or lootboxes. ${ }^{17}$ The growing amount of new types of easily accessible games online which include gambling elements exacerbates the societal concern that minors are being progressively exposed to gambling (De Cock et al., 2018). Online gambling has recently been identified by the Council of Europe as an area of concern for children's healthy development and well-being (Council of Europe, 2018).

The commercialisation of play may significantly affect how individual consumers (including children) operate within a sociocultural and economic framework that shapes their thinking patterns, beliefs and emotions in the marketplace (Arnould and Thompson, 2005). New advertising and marketing techniques arguably help shape this framework for children from a very young age. ${ }^{18}$ The promotion of lifestyles based on consumption may lead children to become more materialistic and attach more value to money (Opree et al., 2014). Research also shows that commercialisation negatively impacts the relationship between parents and children and, finally, can aggravate children's unhealthy lifestyles and cause health problems (Valkenburg, 2014). An illustration can be found in children's changing food choices, as research has revealed that children who played advergames promoting less healthy foods were more likely to select less healthy food options than those who played advergames promoting healthier food options, which may lead to long-term health concerns such as obesity (Montgomery and Chester, 2009). Therefore, the ubiquity of advertising and other commercial messages in children's play experiences, combined with their increasingly personalised and interactive nature, may have a negative impact on several of their rights (Verdoodt, 2020). The child's right to play (Article 31 UNCRC) is affected by the integration of

17 Lootboxes are in-game purchases consisting of a virtual container that awards players with items and modifications in a randomised manner. Lootboxes can be purchased with real or virtual currency by players, who in return get to open a mystery box containing a bunch of lower-end rewards, with a chance of obtaining an exclusive, rare item (Lambrecht and Wauman, 2017).

18 For instance, the UN Special Rapporteur in the field of cultural rights also underlines the potential risk of normalising commercialisation when embedding marketing and advertising programmes in the school environment (Shaheed, 2013). 
commercial elements into play. Play - in digital form - has an important function in a child's development. The concept of "play" under Article 31 UNCRC 'refers to unstructured informal activities of children that are not controlled by adults' (or others for that matter) (David, 2006: 24). Moreover, it covers activities that are based on free choice and are not compulsory (David, 2006). Manipulating children by hiding advertisements in games or nudging them towards gambling or buying goods by overriding their capacity for reflection or without them noticing, calls children's ability to make informed commercial decisions into question. Such exploitation may have long-lasting effects on their development and thereby affect their best interests as well as their rights to development and freedom of thought (Verdoodt, 2020).

However, the child's best interests (Article 3 UNCRC) and development rights (Article 6 UNCRC) have an important participation dimension that should be kept in mind. Children will be unable to make a successful transition to adulthood unless they are given opportunities to practice decision-making skills (Fortin, 2009), also independently from their parents in accordance with their evolving capacities (Article 5 UNCRC). This general perspective could be argued also to be valid with regard to commercial decisions, so banning all commercial practices from children's lives would not be compatible with the right to development and may disregard children's evolving autonomy (Verdoodt, 2020). Rather, children need to be protected from being unjustly manipulated for the economic benefit of commercial actors, for instance by acting against aggressive or misleading advertising, hidden gambling and other commercially exploitative practices aimed at children.

\section{4 \\ Digital Child Labour and Economic Exploitation}

In the digital environment, some children have become an important source of income for their families by becoming (social media) influencers, or professional e-Sports players (Bush, 2017). Influencers are (usually) young people with an extensive audience on social media who present themselves as brands in order to sell products of others. Recruiting child influencers is a profitable instrument for companies given that these children can gain the trust and interest of other children because they are able to identify with or want to feel connected to the influencer. Child influencer work - depending on the age of the child - is often arranged and encouraged by parents and videos are staged and professionally edited by parents (Volpe, 2019; Wong, 2019). In order to play their part, children can be required to dress up on a daily basis, follow scripts, and act in videos recorded by their parents while (knowingly or not) 
promoting products or services to their peers. Second, e-Sports has become increasingly popular amongst the younger audiences and consequently has turned into a lucrative business. For instance, during the first Fortnite World Cup, organised in the summer of 2019, a 16-year old gamer won three million dollars in prize money (Meadows, 2019). Some Fortnite players are celebrities across the globe, with large social-media followings, and make money on sponsor deals and tournaments. Although influencing work or participating in e-Sports may be playful, these activities do not always satisfy the definition of "play" as included in the UNCRC; on the contrary, it bears more resemblance to work (e.g. child performers) and could constitute a new form of child labour (Wong, 2019; Verdoodt et al., 2020). Today, a public discussion concerning the responsibility of brands when the influencer is a child or regarding exploitative contracts with underage e-Sports players (Crook, 2019) is emerging (Russon, 2018; Tabor, 2018; Forrester, 2019; Naisby, 2019; StokelWalker, 2019; Waterson, 2019). However, there has been little discourse in this regard among regulators. ${ }^{19}$

Article 32 UNCRC is generally associated with the protection of children against child labour, including harmful or hazardous work (Swepston, 2012). Influencer or e-Sports activities are usually not "hazardous" because of a lack of imminent or immediate danger, except if the influencer performs dangerous or fatal stunts (Alexander and Horton, 2017; Elliot, 2019) or if the videos end up being used for illicit activities like the production of child sexual abuse material (Lee, 2019; Silva, 2019). Article 32 UNCRC also requires that influencer work is not harmful to a child's health, or physical, mental, spiritual, moral or social development, and it may not interfere with the child's education. In this respect the child's best interests (Article 3 UNCRC) and development (Article 6 UNCRC) are also relevant. This means that these activities may not be overly time-consuming or physically or emotionally demanding (Swepston, 2012). However, if a child wants to become and, then, remain a popular influencer, he or she might have to (very) regularly publish vlogs, pictures and other content on social media platforms. Producing high-quality and entertaining content on a weekly or even daily basis, and similarly, training for an e-Sports tournament, takes a lot of time, and the pressure to continue to perform is high. In both cases, however, under national laws, the protection of children from harmful/hazardous or high-pressure/emotionally demanding child work may

19 However, media reports state that the Dutch Inspectorate for Social Affairs and Employment has started a research project into work by child vloggers; see e.g. https://www.nu.nl/ economie/6o32672/kinderarbeid-of-hobby-inspectie-start-onderzoek-naar-kindvloggers. html. 
be confined to employment relations (Verdoodt et al, 2020), leaving influencer work and other forms of digital work of children like e-Sports unregulated despite their potentially harmful effects and, thus, leaving children largely unprotected but for their parents setting restrictions. Needless to say, the latter may not always happen (sufficiently) if parents are part of and actively encourage influencer work by their children, let alone if the work becomes a highly profitable endeavour.

\section{$5 \quad$ Recommendations}

The digital environment enables economic exploitation of children in a variety of ways and, hence, the protection of Article 32, UNCRC should be considered applicable to these forms of exploitation in order to protect children from such practices. Inspiration can be found in the first comprehensive policy document on the rights of the child in the digital environment worldwide, which was adopted by the Council of Europe in July 2018 - the Recommendation 2018(7) on Guidelines to respect, protect and fulfil the rights of the child in the digital environment. This Recommendation, building on the UNCRC, emphasises that -

States should take measures to ensure that children are protected from commercial exploitation in the digital environment, including exposure to age-inappropriate forms of advertising and marketing. This includes ensuring that business enterprises do not engage in unfair commercial practices towards children, requiring that digital advertising and marketing towards children is clearly distinguishable to them as such, and requiring all relevant stakeholders to limit the processing of children's personal data for commercial purposes (Council of Europe, 2018: 20).

In addition to this general principle, as well as the previously-mentioned restrictions on profiling as put forward by the Council of Europe (2018), a number of other actions could be undertaken. In the following sections we will focus briefly on children's rights impact assessments (section 5.1) and privacy by design (section 5.2 ) respectively, ${ }^{20}$ which both focus particularly on mitigating the harmful impact of automated decision-making and profiling and to a certain extent the commercialisation of play.

20 Parts of this section have previously been discussed in Van der Hof and Lievens, 2018. 


\subsection{Children's Rights Impact Assessments}

Many of the commercial practices that are discussed above affect a number of children's rights. A comprehensive, rights-based approach towards the protection of children from economic exploitation requires conducting children's rights impact assessments (CRIAs), both by policymakers when drafting policies and legislation, and by individuals, organisations and companies before adopting such practices that might have an impact on any of the rights guaranteed in the UNCRC.

The UN Committee on the Rights of the Child, along with many other IG Os and NGOS, recommends the use of CRIAs to evaluate the impact of any proposed law, policy or decision on children's rights (UN Committee on the Rights of the Child, 2013). CRIAs provide a means for implementing all UNCRC rights, and in particular Articles 3 and 12 of the UNCRC, by ensuring a systematic consideration of the best interests of the child and the views and experiences of children (Unicef, 2013). They can help mainstream and embed children's rights principles, standards and processes in the workings of both public and private actors (Collins and Guevara, 2014), to make a child rights-based approach the norm in their decision-making processes (Payne, 2019). Through their involvement in the drafting of a CRIA, individuals may become more aware of and reflect on the position of the child in society. At the same time, quite a number of challenges are associated with undertaking CRIAS - especially by private actors, including lack of child rights awareness, absence of CRIA knowledge and lack of resources (Collins and Guevara, 2014).

The process of conducting a CRIA in itself provides a strong incentive to assess the risks to children's rights resulting from the processing of their personal data and other commercial activities. Two important principles are vital in thinking about CRIAs. First, when undertaking a CRIA, a government, organisation or company should adopt a children's rights perspective that considers the full range of children's rights at stake, including the child's right to be heard (United Nations Committee on the Rights of the Child, 2013b). As we argue above, for instance, advertising that is targeted at children on the basis of profiling may not only process significant amounts of data (Article 16 UNCRC) but may also compartmentalise children and shape their preferences and interests accordingly, ultimately affecting their autonomy and their right to development (Article 6 UNCRC). At the same time, as the long-term impact of some of the risks we have described above is still unclear (children have only recently been growing up in this very commercial digital space), the assessment of how certain practices may entail adverse consequences for the child's well-being and development will not be obvious (Unicef, 2017). This will require more longterm research and evidence. Until this is available, a precautionary approach 
could be adopted (Lievens, 2020). Second, in situations where "protection" factors affecting a child (e.g. implying a limitation or restriction of rights) need to be assessed in relation to measures of "empowerment" (promoting children's skills and understanding), the evolving capacities of the child should be the guiding factor. This means that in certain contexts different measures (be it transparency-enhancing measures or default limits or restrictions) may be considered for younger and older children. Such measures differentiating between children of different ages and maturity levels have already been proposed by scholars and data protection authorities (Montgomery and Chester, 2015; Stoilova et al., 2019; Information Commissioner's Office, 2020).

\subsection{Privacy by Design}

In the context of data protection, "privacy by design" requires that controllers implement data protection principles such as data minimisation (not collecting more data than absolutely necessary), accountability and transparency (Article 5 GDPR) into the design of their data processing systems. It ensures that data protection becomes part and parcel of data processing systems without children and parents necessarily needing to fully comprehend the oftentimes complex technical data processing practices. Also, it provides opportunities to integrate individual (control) rights into the data systems operation, hence, potentially making them both more transparent and effective (Van der Hof and Lievens 2018). Some data protection rights have particular importance in relation to children, such as the right to transparency, the right not to be subjected to profiling as well as the right to be forgotten (Lievens and Verdoodt, 2017; Lievens and Vander Maelen, 2019). In terms of transparency, for instance, a data protection by design solution could entail making transparency an integral part of the process of data processing practices, e.g. by clearly and instantaneously showing important events or changes in data processing systems to users or by giving them a visualisation of and accessible tools to tweak data processing in a control panel or a privacy dashboard as, for example, suggested by the Article 29 Working Party (2018b). Such tools need to be geared to children's expectations, perceptions and experiences. This requires research into what works for children at what ages, given their evolving capacities. A second example relates to the processing of personal data for the purpose of online profiling. Such processing can be designed in ways that automatically rule out personal data which holds attributes pertaining to persons under 18 as well as refraining from applying the results of profiling processes to children. The rationale underlying the privacy by design concept could also be extended to a children's rights by design approach with regard to commercial activities and business' responsibilities with respect to children's rights. 

Exploitation

The right to protection against economic exploitation laid down in Article 32 UNCRC was originally focused on the elimination of child labour. Since the adoption of the UNCRC, a little more than 30 years ago, the world has changed considerably and so has the living and playing environment of children. Their interactions and communications are increasingly mediated by digital technologies, either through the computer devices that they use, such as smart phones, tablets and laptops, or because the toys (or other appliances in their households) have become networked too. ${ }^{21}$ The digital environment that emerges from all these devices being connected to the network of networks and "talking" to each other have an inherently commercial as well as opaque nature. Whereas we used to have dedicated commercial spaces, such as malls or casinos, from which children could more easily be kept away, or which they could only enter accompanied by adults or once they reached a certain age, nowadays such physical, social or legal boundaries have disappeared or are difficult to uphold. At the same time, spaces specifically dedicated to children and free from commercial influences are largely absent from the digital world. Today's spaces are developed by private companies and offered on a for-profit basis where the value is in the personal data of their users that can be re-used or sold for marketing purposes, or in the monetary revenues from advertising, in-app purchases, or gambling. Increasingly, more children spend more time in these highly commercialised digital spaces. Moreover, exploitative practices have materialised in such a way that they are now specifically designed for and become ever more sophisticated in manipulating children into sharing more personal data or spending money in the digital world. Given these qualitative changes to the world that children grow up in, it has become essential to recalibrate the right to protection against economic exploitation and redefine how it pertains to other rights in the Convention. Although the basic elements of economic exploitation can be readily reconceptualised for the digital world, the interaction with other children's rights seems to have changed profoundly with other rights having gained in relevance, such as the right to non-discrimination and the right to privacy. Whereas Article 16 UNCRC prohibits interferences with a child's privacy, recent fundamental rights

21 The Internet of Toys is part of the broader development of the Internet of Things in which many of the appliances that surround us, such as washing machines, watches, cars and thermostats, are being connected to the internet and operated by apps. Moreover, new devices are created to make our lives more convenient and turn our houses into smart homes, such as Google Home, Amazon's Alexa, Apple's Siri and Microsoft's Cortana. 
documents, such as the EU Charter of Fundamental Rights have integrated a fundamental right to data protection (Article $8 \mathrm{CFREU}$ ). The EU data protection framework has recently been modernised and strengthened in order to improve the protection of individuals in an ever-changing, datafied, digital world. Given the recognition of children as a vulnerable group with their own set of fundamental rights, that framework will be crucial in improving the protection of children, their personal data and their rights. However, in order fully to achieve this, it is essential that related children's rights (such as the right to development) are given a stronger position within the data protection framework. Moreover, measures, remedies and regulatory frameworks that might have worked well enough in the pre-networked era are expected to be largely ineffective or in need of adjustment and reinforcement today. We may need to rethink the protection of children against harmful and manipulative marketing strategies that become more and more sophisticated, particularly also given that industry self-regulation currently still plays an important role in advertising regulation. Self-regulatory measures in this context often predominantly rely on transparency - a principle that does not work well with dark patterns. Firmer action by governments to protect children is needed, which starts by recognising that children, while playing, are under the threat of becoming subjected to economic exploitation and which should be followed by dedicated action to grant every child the right to play safely and in a child-friendly manner, without commercial or any other kind of exploitation. Finally, novel arrangements around child work in the digital world, such as children as vloggers and influencers, or children engaging in e-Sports, may not always fit within the legal frameworks that were once developed for the analogue world. This is likely to leave children unprotected from harmful or unhealthy situations. Whenever the application or enforcement of existing "offline" norms is frustrated by socio-technological developments, governments should adjust laws in order to remedy the situation by ensuring norms are given full effect in the digital world as well (Koops and Prins, 2000). A complete review of child labour law seems appropriate to ensure that protection and participation rights of children are updated and better coordinated with regard to online child work.

\section{Acknowledgement}

This article is a significantly extended and revised version of the authors' submission to the United Nations Committee on the Rights of the Child in view of their intention to draft a General Comment on children's rights in relation to the digital environment (May 2019). The submission is available here: https://www. ohchr.org/Documents/HRBodies/CRC/GCChildrensDigitalEnvironment/ OtherStakeholders/EvaLievensSimonevanderHofetal.pdf. 


\section{References}

_—, “'No-Fly List Flags More Canadian Toddlers as Security Risks”, CBCNews (4January 2016): https://www.cbc.ca/news/canada/toronto/no-fly-list-flags-morecanadiantoddlers-as-security-risks-1.3388927.

Elliot, Annabel, "Instagrammers fall ill at 'idyllic' lake that is actually a toxic dump", The Telegraph (16 July 2019): https://www.telegraph.co.uk/travel/news/ instagrammers-flock-to-toxic-lakes-monte-neme-siberian-seychelle/.

Alexander, H. and Horton, H., "Minnesota teenage shoots boyfriend dead in YouTube stunt to 'boost online profile', The Telegraph (29 June 2017): https://www. telegraph.co.uk/news/2017/o6/29/us-woman-shoots-boyfriend-dead-youtubestunt-boost-online-profile/.

Arnould, E. J. and Thompson, C. J., "Consumer Culture Theory (CCT): Twenty Years of Research", Journal of Consumer Research, 2005 (31(4)), 868-882. DOI: $10.1086 / 426626$.

Article 29 Working Party, Guidelines on Automated individual decision-making and Profiling for the purposes of Regulation 2016/679 (6 February 2018a): https:// ec.europa.eu/newsroom/Article29/item-detail.cfm?item_id=612053.

Article 29 Working Party, Guidelines on Transparency under Regulation 2016/679 (11 April 2018b): http://ec.europa.eu/newsroom/Article29/item-detail.cfm?item_id=622227.

Barnhill, A., "I'd Like to Teach the World to Think: Commercial Advertising and Manipulation", Journal of Marketing Behavior 2016 1(3-4), 307-328. DOI: 10.1561/107.00000020.

BEUC, Data Collection, Targeting and Profiling of Consumers Online (2010): https:// www.beuc.eu/publications/2010-oo101-o1-e.pdf.

Bush, R., "Protecting Children and Young People in Esports", The Esports Observer, (21 August 2017): https://esportsobserver.com/protecting-children-young-peopleesports/.

Capps, K., Childhood Asthma: A Lingering Effect of Redlining, CityLab. (23 May 2019): https:/www.citylab.com/equity/2019/o5/redlining-segregation-asthma-healtheffect-research-data-map/590143/.

Chaudron, S., Young Children (o-8) and digital technology: A qualitative exploratory study across seven countries (JRC93239), Publications Office of the European Union (2015). DOI: 10.2788/00749.

Chiarella, M. L., The Regulation of Child Consumption in European Law: Rights, Market and New Perspectives. Social Science Research Network (2009): https://papers.ssrn. com/abstract $=1440251$.

Children's Commissioner for England, Who knows what about me? (2018): https://www. childrenscommissioner.gov.uk/publication/who-knows-what-about-me/. 
Collins, T. M. and Guevara, G., "Some Considerations for Child Rights Impact Assessment (CRIAs) of Business", Revue générale de droit 2014, (44 (1)), 153-192.

Council of Europe, The protection of individuals with regard to automatic processing of personal data in context of profiling: Recommendation CM/Rec(2010)13 adopted by the Committee of Minsters of the Council of Europe on 23 November 2010 and explanatory memorandum (2010): https://rm.coe.int/16807096c3.

Council of Europe, Recommendation CM/Rec(2018)7 of the Committee of Ministers to member States on Guidelines to respect, protect and fulfil the rights of the child in the digital environment (2018): https://rm.coe.int/guidelines-to-respect-protect-and-fulfilthe-rights-of-the-child-in-th/168o8d881a.

Crook, J. "Pro gamer Tfue files lawsuit against esports org over 'grossly oppressive' contract”, TechCrunch (21 May 2019): http://social.techcrunch.com/2019/05/21/ pro-gamer-tfue-files-lawsuit-against-esports-org-over-grossly-oppressive-contract/.

David, P., Article 31: The right to leisure, play and culture (Martinus Nijhoff Publishers, 2006). DOI: 10.1163/ej.9789oo4148826.i-34.

De Cock, R., Zaman, B., Van Mechelen, M. and Huyghe, J., "Early Gambling Behaviour in Online Games. Parental Perspectives vs. What Children Report", in Mascheroni G., Ponte C. and Jorge A. (eds.), Digital Parenting: The Challenges for Families in the Digital Age(Nordicom,2018):http://urn.kb.se/resolve?urn=urn:nbn:se:norden:org:diva-5398.

European Commission, Commission Staff Working Document-Guidance on the Implementation/Application of Directive 2005/29/EC on Unfair Commercial Practices, $S W D(2016) 163$ Final (2016): http://ec.europa.eu/justice/consumer-marketing/files/ ucp_guidance_en.pdf.

European Parliament and Council, Directive 2005/29/EC concerning unfair business-toconsumer commercial practices in the internal market (Unfair Commercial Practices Directive) [2005] OJ L 149 (2005): https://eur-lex.europa.eu/legal-content/EN/ TXT/?uri=CELEX:32005Loo29.

European Parliament and Council, Regulation (EU) 2016/679 of 27 April 2016 on the protection of natural persons with regard to the processing of personal data and on the free movement of such data, and repealing Directive 95/46/EC (General Data Protection Regulation) OJ 4 May 2016, L119/1 (2016).

Forrester, J., Industry Responds to BBC Panorama Documentary on Influencer Marketing (12 February 2019): https://talkinginfluence.com/2019/o2/12/bbc-panoramadocumentary-influencer-marketing/.

Fortin, J., Children's Rights and the Developing Law (Cambridge University Press, 2009). DOI: $10.1017 / \mathrm{CBO} 9781139168625$.

Gibbs, S., "WhatsApp raises minimum age to 16 for Europeans ahead of GDPR". The Guardian (25 April 2018): http://www.theguardian.com/technology/2018/apr/25/ whatsapp-raises-minimum-age-16-europeans-facebook-gdpr-eu. 
Harris, M., "Virtual assistants such as Amazon's Echo break US child privacylaw, experts say", The Guardian (26 May 2016): http://www.theguardian.com/technology/2016/ may/26/amazon-echo-virtual-assistant-child-privacy-law.

Hern, A. (2019a, February 28). "TikTok video-sharing app fined for collection of children's data", The Guardian (28 February 2019a): https://www.theguardian. com/technology/2019/feb/28/tiktok-video-sharing-app-fined-for-collection-ofchildrens-data.

Hern, A., "TikTok under investigation over child data use". The Guardian (2 July 2019b): https://www.theguardian.com/technology/2019/jul/o2/tiktok-under-investigationover-child-data-use.

Information Commissioner's Office, Age appropriate design: A code of practice for online services. Consultation document (2019): https://ico.org.uk/media/about-the-ico/ consultations/2614762/age-appropriate-design-code-for-public-consultation.pdf.

Information Commissioner's Office, (2020). Age appropriate design: A code of practice for online services. Final version: To be laid in Parliament (2020): https://ico.org.uk/ media/for-organisations/guide-to-data-protection/key-data-protection-themes/ age-appropriate-design-a-code-of-practice-for-online-services-2-1.pdf.

Kang, C., “Consumer Groups Accuse Facebook of Duping Children”. The New York Times (22 February 2019): https://www.nytimes.com/2019/o2/21/technology/facebookchildren-privacy.html.

Kelion, L., “Amazon sued over Alexa child recordings", BBC News (14 June 2019): https:// www.bbc.com/news/technology-48623914.

Koops, B.-J. and Prins, C., "Governments on Internationalisation and ICT Law. The Positions of Germany, France, the United Kingdom, and the United States" in Koops B.-J., Prins C. and Hijmans H. (eds.), ICT Law and Internationalisation, a Survey of Government Views Information (Den Haag: Kluwer Law International, 2000): http:// www.philadelphia.edu.jo/external/home/85-internationalisation/195058-ict-lawand-internationalisation-a-survey-of-government-views-.html.

Lambrecht, I. and Wauman, J., "Lootboxes in Videogames: Gambling at the Battlefront (Part I)”. CITIP Blog (19 December 2017): https://www.law.kuleuven.be/citip/blog/ lootboxes-in-videogames-gambling-at-the-battlefront-part-i/.

Lee, C. F., Dave., "YouTube bans comments on all videos of kids", BBC News (28 February 2019): https://www.bbc.com/news/technology-47408969.

Lievens, E., "The rights of the child in the digital environment: from empowerment to de-responsibilisation" in 5 Rights, Privacy, Security and Freedom: Being a Child in the Digital World (2020) (forthcoming).

Lievens, E., Livingstone, S., McLaughlin, S., O’Neill, B. and Verdoodt, V., “Children's Rights and Digital Technologies" in Kilkelly U. and Liefaard T. (eds.), International Human Rights of Children (Springer: Singapore, 2018) DOI: 10.1007/978-981-10-3182-3_16-1. 
Lievens, E. and Vander Maelen, C., "A Child's Right to be Forgotten: Letting Go of the Past and Embracing the Future?", Latin American Law Review 2019 (2), 61-79. DOI: 10.29263/laro2.2019.03.

Lievens, E. and Verdoodt, V., "Looking for needles in a haystack: Key issues affecting children's rights in the General Data Protection Regulation", Computer Law \& Security Review 2017 (34(2)), 269-278. DOI: 10.1016/j.clsr.2017.09.007.

Lupton, D. and Williamson, B., "The datafied child: The dataveillance of children and implications for their rights", New Media \& Society 2017 (19(5)), 780-794. DOI: $10.1177 / 1461444816686328$.

Martin, K., Gentrification, Educational Redlining, and the Urban Neighborhood School Green \& Write (26 April 2016): https://edwp.educ.msu.edu/green-and-write/2016/ gentrification-educational-redlining-and-the-urban-neighborhood-school/.

Meadows, B. A. G., "Fortnite World Cup: The \$3om tournament shows esports' future is already here". The Guardian (30 July 2019): https://www.theguardian.com/ sport/2019/jul/3o/fortnite-world-cup-esports.

Milkaite, I. and Lievens, E., “The Internet of Toys: Playing Games with Children's Data?” in Mascheroni G. and Holloway D. (eds.), The Internet of Toys: Practices, Affordances and the Political Economy of Children's Play (Palgrave Macmillan, 2019). DOI: 10.1007/978-3-030-10898-4.

Milkaite, I. and Lievens, E., "Child-Friendly Transparency of Data Processing in the EU: From Legal Requirements to Platform Policies", Journal of Children and Media 2020 (14(1)). DOI: 10.1080/17482798.2019.1701055.

Montgomery, K. C. and Chester, J., "Interactive Food and Beverage Marketing: Targeting Adolescents in the Digital Age", Journal of Adolescent Health 2009 (45(3, Supplement)). DOI: 10.1016/j.jadohealth.2009.04.006.

Montgomery, K. C. and Chester, J., "Data Protection for Youth in the Digital Age: Developing a Rights-based Global Framework", European Data Protection Law Review 2015 (1(4)). DOI: 10.21552/EDPL/2015/4/6.

Naisby, N., Influencer Marketing and Brand Responsibility (14 March 2019): http:// digitalmarketing.temple.edu/nnaisby/2019/o3/14/influencer-marketing-andbrand-responsibility/.

Norwegian Consumer Council, \#Toyfail. An analysis of consumer and privacy issues in three internet-connected toys (2016): https://fil.forbrukerradet.no/wp-content/ uploads/2016/12/toyfail-report-desember2o16.pdf.

Norwegian Consumer Council, Every step you take (2018): https://www.forbrukerradet. no/undersokelse/2018/every-step-you-take/.

OECD, Recommendation on the Protection of Children Online (2012): http://www.oecd. org/sti/ieconomy/protecting-children-online.htm. 
Opree, S. J., Buijzen, M., van Reijmersdal, E. A. and Valkenburg, P. M., “Children's Advertising Exposure, Advertised Product Desire, and Materialism: A Longitudinal Study", Communication Research 2014 (41(5)). DOI: 10.1177/0o93650213479129.

Payne, L., "Child Rights Impact Assessment as a policy improvement tool", The International Journal of Human Rights 2019, (23(3)), 408-424.

Russon, M.-A., “Are Instagram stars facing a brand backlash?”, BBC News (22 June 2018): https://www.bbc.com/news/business-44539536.

Shaheed, F., Report of the Special Rapporteur in the Field of Cultural Rights (A/69/286) (2013): http://digitallibrary.un.org/record/755488.

Silva, M., "Video app TikTok fails to remove online predators", BBC News (5 April 2019): https://www.bbc.com/news/blogs-trending-47813350.

Stoilova, M., Livingstone, S. and Nandagiri, R., (2019). Children's data and privacy online: Growing up in a digital age. Research findings (2019), London School of Economics and Political Science: http://www.lse.ac.uk/my-privacy-uk/Assets/Documents/ Childrens-data-and-privacy-online-report-for-web.pdf.

Stokel-Walker, C., (2019, February 3). "Instagram: Beware of bad influencers...", The Observer (3 February 2019): https://www.theguardian.com/technology/2019/ feb/o3/instagram-beware-bad-influencers-product-twitter-snapchat-fyre-kendalljenner-bella-hadid.

Swepston, L., A Commentary on the United Nations Convention on the Rights of the Child, Article 32: Protection from Economic Exploitation (Brill: Nijhoff, 2012): https://brill. com/view/title/11644.

Tabor, E., "Doing It for the Kid(fluencer)s: How Brands Can Ethically Engage in the Digital Kids' Market” (25 April 2018): https://www.adweek.com/digital/doing-it-forthe-kidfluencers-how-brands-can-ethically-engage-in-the-digital-kids-market/.

Timberg, C., "YouTube says it bans preteens from its site. But it's still delivering troubling content to young children", Washington Post 14 March 2019a): https:// www.washingtonpost.com/technology/2019/o3/14/youtube-says-it-bans-preteensits-site-its-still-delivering-troubling-content-young-children/.

Timberg, C., "Consumer groups accuse Amazon of illegally collecting data on children", Washington Post (9 May 2019b): https://www.washingtonpost.com/business/ technology/2019/05/o8/2af2d282-71cc-11e9-b5ca-3d72a9fa8ffi_story.html.

UNICEF, Children's Rights in Impact Assessments. A guide for integrating children's rights into impact assessments and taking action for children (2013): https://www. unicef.org/csr/css/Children_s_Rights_in_Impact_Assessments_Web_161213.pdf.

UNICEF, Children and the Data Cycle: Rights and Ethics in a Big Data World, Innocenti Working Paper 2017-05: https://www.unicef-irc.org/publications/pdf/IWP_2017_05. pdf.

United Nations Committee on the Rights of the Child, UNCRC General Day of Discussion 1993, Economic Exploitation of Children: UN Doc CRC/C/20 (1993). 
United Nations Committee on the Rights of the Child, General Comment No. 14 on the right of the child to have his or her best interests taken as a primary consideration (art. 3, para. 1), (CRC/C/GC/) (2013a).

United Nations Committee on the Rights of the Child. General Comment No. 16 on State obligations regarding the impact of the business sector on children's rights, UN Doc $\mathrm{CRC} / \mathrm{C} / \mathrm{GC} / 16$ (2013b).

United Nations Committee on the Rights of the Child, General Comment No. 20 on the implementation of the rights of the child during adolescence, UN Doc CRC/C/GC/2O (2016).

Valkenburg, P. M., Schermgaande jeugd. Overjeugd en media (Amsterdam: Promotheus/ Bert Bakker, 2014): https://dare.uva.nl/personal/search?metis.record.id=442566.

Van der Hof, S., "Online profiling of children in Europe a legal perspective, Dynamic Identity Workshop" (2015).

Van der Hof, S., Children and data protection from the perspective of children's rightsSome difficult dilemmas under the General Data Protection Regulation (Wolters Kluwer: Belgium, 2018).

Van der Hof, S., Klik, Swipe, like... Je Bent Verkocht! Opgroeien in Een Wereld van Surveillance Kapitalisme (2019): https://www.student.universiteitleiden.nl/binaries/ content/assets/algemeen/oraties/dies-2019/diesrede-van-der-hof.pdf.

Van der Hof, S. and Hannema, T., "Veilig opgroeien in een wereld vol algoritmes-De bijzondere bescherming van kinderen onder art. 22 Algemene verordening gegevensbescherming", Privacy \& Informatie (2018): https://www.recht.nl/vakliteratuur/ privacy/artikel/454649/veilig-opgroeien-in-een-wereld-vol-algoritmes-debijzondere-bescherming-van-kinderen-onder-art-22-algemene-verordeninggegevensbescherming/.

Van der Hof, S. and Lievens, E., "The Importance of Privacy by Design and Data Protection Impact Assessments in Strengthening Protection of Children's Personal Data Under the GDPR", Communications Law 2018 (23(1)).

Van der Hof, S., Lievens, E. and Milkaite, I., "The protection of children's personal data in a data-driven world: A closer look at the GDPR from a children's rights perspective" in Liefaard T., Rap S. and Rodrigues P. (eds.), Monitoring Children's Rights in the Netherlands. 30 Years of the UN Convention on the Rights of the Child (Leiden University Press, 2020).

Varadan, S., "The Principle of Evolving Capacities under the UN Convention on the Rights of the Child", The International Journal of Children's Rights 2019 (27(2)), 306-338. DOI: $10.1163 / 15718182-02702006$.

Veale, M. and Edwards, L., "Clarity, surprises, and further questions in the Article 29 Working Party draft guidance on automated decision-making and profiling", Computer Law \& Security Review 2018 (34(2)), 398-404. DOI: 10.1016/j.clsr.2017.12.002. 
Verdoodt, V., Children's Rights and Commercial Communication in the Digital Era (Intersentia, 2020).

Verdoodt, V., Clifford, D. and Lievens, E., “Toying with children's emotions, the new game in town? The legality of advergames in the EU", Computer Law \& Security Review 2016 (32(4)), 599-614. DOI: 10.1016/j.clsr.2016.05.007.

Verdoodt, V. and Lievens, E., "De AVG Bekeken Vanuit Een Kinderrechtenperspectief Pluspunten, Knelpunten \& Vraagstukken”, Computerrecht $2017 \mathrm{a}$.

Verdoodt, V. and Lievens, E., "Targeting children with personalised advertising: How to reconcile the best interests of children and advertisers" in Vermeulen G. and Lievens E. (eds.), Data Protection and Privacy Under Pressure: Transatlantic tensions, EU surveillance, and big data (Maklu, 2017b).

Verdoodt, V., van der Hof, S. and Leiser, M., "Child Labour and Online Protection in a World of Influencers" in Goanta C. and Ranchiordas S. (eds.), The Regulation of Social Media Influencers (Edward Elgar, 202O).

Vetzo, M., Gerards, J. H. and Nehmelman, R., Algoritmes en grondrechten (Den Haag: Boom Juridisch, 2018).

Volpe, A., How Parents of Child Influencers Package Their Kids' Lives for Instagram. The Atlantic (28 February 2019): https://www.theatlantic.com/family/archive/2019/o2/ inside-lives-child-instagram-influencers $/ 583675 /$.

Waldman, A. E., Privacy as Trust. Information privacy for an Information Age (Cambridge Core, 2018) DOI: 10.1017/9781316888667.

Waterson, J., "Instagram influencer Mrs Hinch investigated by advertising body", The Guardian (5 June 2019): https://www.theguardian.com/media/2019/jun/05/ instagram-influencer-mrs-hinch-investigated-by-advertising-body.

Wendling, M., (2017). "YouTube child protection mechanism 'failing”, BBC News: http:// www.bbc.com/news/blogs-trending-40808177.

Wong, J. C., “'It's not play if you're making money': How Instagram and YouTube disrupted child labor laws", The Guardian, 24 April 2019): https://www.theguardian. $\mathrm{com} / \mathrm{media} / 2019 / \mathrm{apr} / 24 /$ its-not-play-if-youre-making-money-how-instagram-andyoutube-disrupted-child-labor-laws. 